\title{
Frozen Drops Observed at Fairbanks, Alaska
}

\author{
Ken-ichi Sakurai* and Takeshi OHTAKE**
}

\begin{abstract}
Frozen drops were observed at Fairbanks, Alaska in early winter of 1976 . They fell along with dendritic snow crystals and displayed a polycrystalline structure. From the difference in falling velocity between the frozen drops and the snow crystals, it is concluded that the drops were formed in the upper part of a cloud and were frozen during their fall by collision with snow crystals which were formed in the lower part of the cloud.
\end{abstract}

\section{Introduction}

In the polar regions, physical observations of clouds have been recently carried out by Ohtake (1978), Magono et al. (1978) and Kikuchi and Hogan (1979). They mainly observed snow crystals in order to find the relation between crystal shapes and the meteorological conditions. From observations in northern Canada, Magono et al. (1978) found that supercooled water drops and frozen drops fell when the air temperature on the ground was about $-12^{\circ} \mathrm{C}$. They concluded from analyses of sounding curves that these drops were formed by the melting of graupel or rimed snow crystals while falling through a warm layer whose temperature was about $-9^{\circ} \mathrm{C}$. Ohtake (1978) and Kikuchi and Hogan (1979) found snow crystals which were generated from supercooled droplets at the South Pole Station.

The authors observed frozen drops falling along with dendritic snow crystals at Fairbanks, Alaska. In this paper, their formation process associated with the meteorological conditions will be discussed.

\section{Observation Results}

Frozen drops were observed at Fairbanks (64. $50^{\prime} \mathrm{N}, 147^{\circ} 52^{\prime} \mathrm{W}$ ) from 1015 to 1630 AST (Alaska

* Department of Earth Science, Hokkaido University of Education at Asahikawa, 070 Japan.

* Geophysical Institute, University of Alaska, Fairbanks, Alaska 99701 U.S.A.
Standard Time) on October 26, 1976. Fig. 1(a), (b) and (c) are photomicrographs of the frozen drops taken by a polarizing microscope. As seen in the figures, most of them stuck on the surface of dendritic or plane snow crystals (Figs. 1(a) and (b)). Moreover, a few frozen drops fell individually as shown in Fig. 1(c). The frozen drops have the polycrystalline structure and a spike as characteristics of freezing. Also, some frozen drops have small plane crystals which grew on their surface during falling as shown in Fig. 2. On the other hand, snow crystals with cloud droplets were also observed simultaneously. Most of the cloud droplets froze in single-crystalline form.

The frozen drops, cloud droplets and snow crystals have a size range, mean size and falling velocity as described in Table 1 .

From the table, it is seen that the frozen drops have a diameter as large as small raindrops or drizzle. The falling velocity of drops corresponding to a mean diameter of $203 \mu \mathrm{m}$ is $72 \mathrm{~cm} / \mathrm{s}$. On the other hand, the diameter of cloud droplets which were captured by a snow crystal ranges from 20 to $70 \mu \mathrm{m}$ with a mean diameter of $35 \mu \mathrm{m}$. This droplet size distribution agrees generally with those of cumulus clouds. Snow crystals which are dendritic or plate type crystals have a size range from 800 to $2540 \mu \mathrm{m}$ with a mean diameter of $1480 \mu \mathrm{m}$.

The distribution of falling velocity of these 


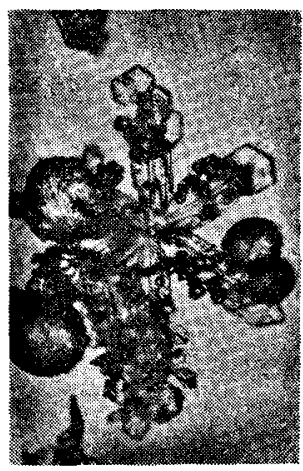

(a)

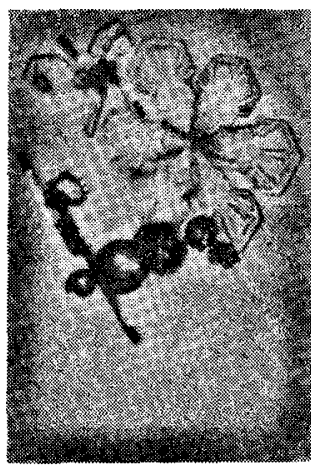

(b)

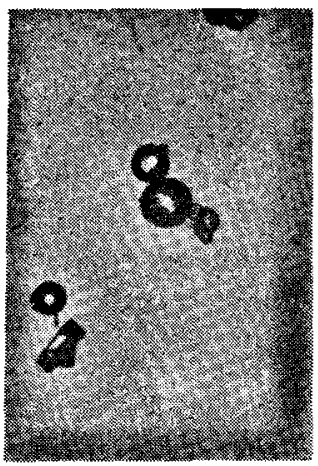

(c)

Fig. 1 Frozen drops and snow crystals

$\overline{200 \mu \mathrm{m}}$

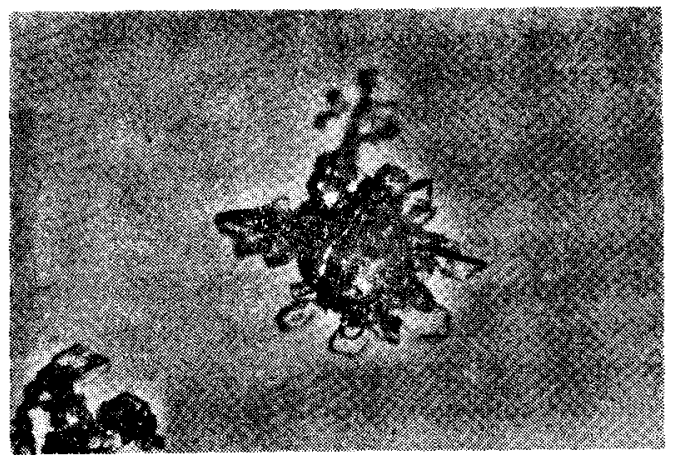

$200 \mu \mathrm{m}$

Fig. 2 Frozen drop with small plane crystals

Table 1. The size range, mean size and falling velocity of particles observed at Fairbanks, Alaska

\begin{tabular}{l|rrr|c}
\hline & \multicolumn{3}{|c|}{$\begin{array}{c}\text { Diameter } \\
(\mu \mathrm{m})\end{array}$} & $\begin{array}{c}\text { Falling Velocity* } \\
(\mathrm{cm} / \mathrm{s})\end{array}$ \\
\cline { 2 - 5 } & Min. Max. Mean & \\
Frozen drop & 76 & 480 & 203 & $72^{* *}$ \\
Cloud droplet & 20 & 70 & 35 & $3.4^{* *}$ \\
Snow crystal**** & 800 & 2540 & 1480 & $31^{* * * *}$ \\
\hline
\end{tabular}

* The falling velocity indicated applies to particles with the listed mean diameter.

** The values are estimated from the table of Mason's book (1971).

*** Diameter of snow crystal is a diagonal length.

**** The value is taken from Nakaya and Terada (1953).

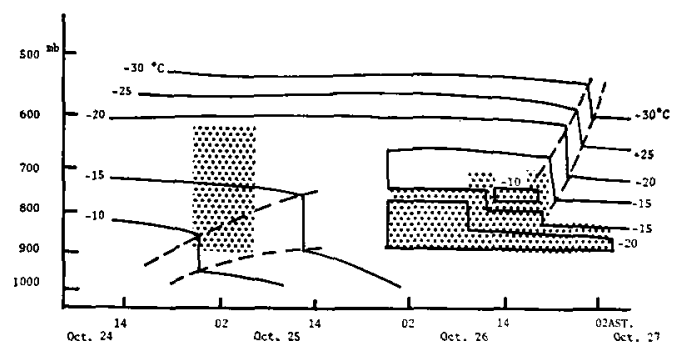

Fig. 3 Time sequence of the upper air conditions at Fairbanks, 24-27 October, 1976. Shaded areas show water saturation zones.

particles suggests that the frozen drops which have the largest velocities probably swept other particles while falling. The freezing might have.occurred when the drops were falling through a snow cloud.

Fig. 3 is a time plot which is made from radiosonde soundings at Fairbanks. In the figure, solid lines indicate isotherms drawn at intervals of $5^{\circ} \mathrm{C}$ and dashed lines show the fronts. Moreover, shaded areas show where the difference between air temperature and dew point is zero. It is suggested that these areas correspond to the cloud. After the front passed on October 25, there was cold air inflow into the interior of Alaska. The lowest temperature in the saturated air aloft was $-20.3^{\circ} \mathrm{C}$ at 1400 on the 26 th. Also, the air lower than the $750 \mathrm{mb}$ level had high moisture. On the other hand, warm air whose temperature was $-9.8^{\circ} \mathrm{C}$ was found above the cold air. There was, therefore, a very strong inversion between both layers when the frozen drops were observed. 


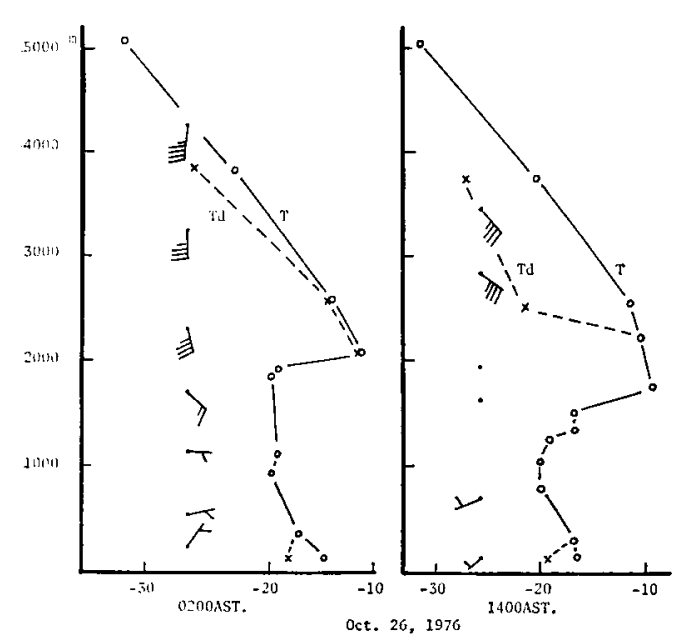

Fig. 4 Upper air sounding made at Fairbanks at 0200 AST and 1400 AST, October 26, 1976.

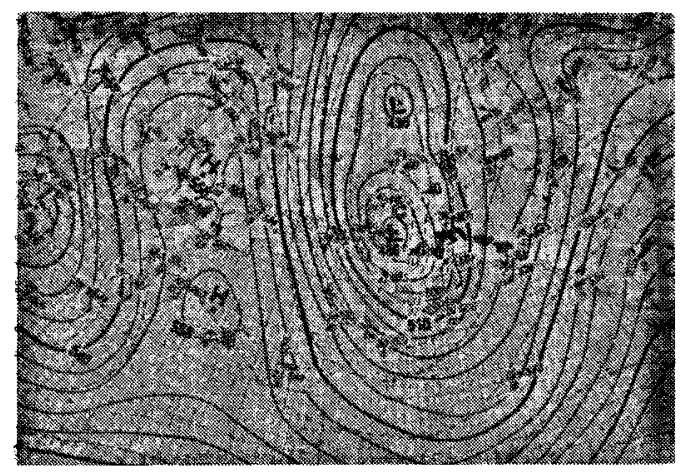

Fig. 50200 AST. Oct. 26, 1976 $500 \mathrm{mb}$ Weather Map

The shape of the snow crystals coincides with that of the crystals estimated from Nakaya's diagram. It is, therefore, suggested from the facts mentioned above that the supercooled drops were formed in the upper a cloud. The frozen drops may be produced by freezing of the supercooled drops falling through the snow cloud. Also, the cloud droplets were distributed in the whole cloud.

Profiles of air temperature, dew point and wind at 0200 and 1400 on the 26th are shown in Fig. 4. From the figure it is seen that the air is separated into two parts; one is a cold and saturated air layer lower than about $2000 \mathrm{~m}$ above sea level and another is warm and subsaturated air above the inversion layer at 0200 on 26th. According to the wind profile at this time, the cold air came from the interior of northern Canada and the warm air penetrated from the north Pacific to Alaska. The currents of the upper and warm air at $500 \mathrm{mb}$ (about $5100 \mathrm{~m}$ above sea surface) are shown in Fig. 5. It is seen from a weather map that the upper air traveled across the Alaska Range (the highest mountain is Mt. McKinley; $6194 \mathrm{~m}$ ) and then reached the Tanana Valley. When the air which crosses the mountains flows down the lee slope, the air temperature may be raised and the dew point may be lowered. This situation is shown in Fig. 4 by profiles of air temperature and dew point at 1400 on the 26th above the $2500 \mathrm{~m}$ level. Moreover, the inversion layer was forcefully lowered several hundred meters.

\section{Conclusion}

Magono et al. (1978) have reported that large frozen and unfrozen drops were formed by melting of graupel or rimed snow crystals in the Arctic region. However, large frozen drops observed at Fairbanks were not formed by melting of ice particles but by the growth of supercooled droplets because there was no snow cloud above the warm layer. From the fact that the origin of warm air is the north Pacific, it is suggested that the large supercooled drops were produced by the activation of giant nuclei contained in the maritime air mass. On the other hand, snow crystals with cloud droplets were formed in the lower part of a cloud in which the air temperature was suitable for the growth of dendritic or plate crystals as reported by Magono and Lee (1966) who had classified the natural snow crystals according to the air temperature.

\section{Acknowledgement}

This research was supported by the Ministry of Education, Japan and State of Alaska funds appropriated to the Geophysical Institute.

\section{References}

Kikuchi, K. and Hogan, A. W., 1979: Properties of diamond dust type ice crystals observed in summer season at Amundsen-Scott South Pole Station, Antarctica. J. Met. Soc. Japan, 57, 180-190.

Magono, C. and Lee, C. W., 1966: Meteorological classification of natural snow crystals. J. Fac. Sci., Hokkaido Univ., Ser. VII, 2, 321-335.

Magono, C., 1978: Snow crystals in Arctic Canada. Hokkaido University.

Mason, B. J., 1971: The physics of clouds. 2nd Ed. 
Oxford Univ. Press, London, 594 pp.

Nakaya, U. and Terada, T., 1935: Simultaneous observations of the mass, falling velocity and form of individual snow crystals. J. Fac. Sci., Hokkaido Univ., Ser. II, 1, 191.
Nakaya, U., 1954: Snow crystal. Harvard Univ. Press. Ohtake, T., 1978: Atmospheric ice crystals at South Pole in summer. Antarct. J. of U.S., 8, 4, 174175.

\section{要 旨}

1976年冬期アラスカ・フェアバンクス市において凍結雨滴が観測された。これらは多結晶の構造 をもっていた，同時に採取された雪結晶, 雲粒と東結雨滴との落下速度の違いから, 雨滴は雲の上 部で形成し落下途中で雪結晶との衝突により棵結したものと思われる.

(1981年 2 月17日受付, 4 月 3 日受理) 